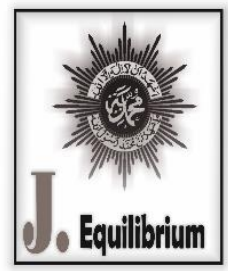

\title{
Daya Tarik Interaksi Dunia Maya (Studi perilaku Phubbing Generasi Milenial)
}

\author{
Reski P \\ Pendidikan Sosiologi Antropologi, Universitas Lambung Mangkurat \\ Email: reski@ulm.ac.id
}

\begin{abstract}
The popularity of smartphones that can not be separated from human life and become increasingly loved by the millennial generation, actually there is nothing wrong with the presence of the smartphone because every product created has a good purpose, only sometimes in use, there are individuals who abuse or just overdo it in its use. This is where the starting point is as improper use of a smartphone, giving birth to symptoms or behaviors as a result of its existence. One such behavior is Phubbing. Phubbing is an anti-social behavior that prefers to interact through cyberspace than the real world. Phubbing phenomenon has spread to almost every level of society both the age, occupation, education, and gender, including millennial generation, which is not spared from the grip of that behavior. It is often seen that people gather together but are busy with their respective activities with smartphones. It is often seen that people gather together but are busy with their respective activities with smartphones. This research uses a qualitative method. Data collection techniques are done by observation, interview, and documentation. This research concludes that: 1 . The cause of phubbing behavior in millennial generation is Diverting boredom, Avoiding unwanted topics of conversation, and friends around also doing phubbing. 2. The pattern of interaction developed by millennials in cyberspace when doing phubbing is Social Interaction between Individuals and Social Interaction between Individuals and Groups.
\end{abstract}

Keywords : Millennial Generation, Phubbing, Virtual World Interaction.

Abstrak. Popularitas smartphone yang tidak bisa dipisahkan dari kehidupan manusia dan menjadi kian digandrungi oleh genarasi milenial, sebenarnya tidak ada yang salah dari kehadiran smartphone tersebut karena setiap produk yang diciptakan itu mempunyai tujuan yang baik, hanya terkadang di dalam penggunaannya ada oknum yang menyalahgunakan ataupun sekedar berlebihan dalam penggunaannya. Disinilah kemudian titik tolak sebagai penggunaan smartphone yang tidak semestinya sehingga melahirkan gejala ataupun perilaku -perilaku sebagai akibat keberadaraannya. Salah perilaku tersebut yaitu Phubbing. Phubbing adalah sebuah perilaku anti sosial yang lebih menyukai untuk berinteraksi melalui dunia maya dibanding dunia nyata. Fenomena Phubbing telah menyebar ke hampir setiap lapisan masyarakat baik tingkat Umur, Pekerjaan, Pendidikan maupun Jenis kelamin termasuk generasi milenial yang saat ini tidak luput dari cengkraman perilaku itu. Sering terlihat bahwa orang-orang berkumpul bersama tetapi sibuk dengan aktivitas masing-masing dengan smartphone. Penelitian ini menggunakan metode kualitatif. Teknik pengumpulan data dilakukan dengan pengamatan, wawancara, dan dokumentasi. Penelitian ini menghasilkan kesimpulan bahwa: 1. Penyebab perilaku phubbing pada generasi milenial adalah Mengalihkan perasaan bosan, Menghindari topik pembicaraan yang tidak disukai, dan Teman disekitar juga melakukan phubbing. 2. Pola interaksi yang dibangun generasi milenial di dunia maya saat melakukan phubbing adalah Interaksi Sosial antar Individu dan Interaksi Sosial Antar Individu dan Kelompok.

Kata Kunci : Generasi Milenial, Phubbing, Interaksi Dunia Maya. 


\section{PENDAHULUAN}

Manusia adalah makhluk sosial yang senantiasa membutuhkan manusia lain di sekitarnya. Sehingga setiap individu akan bertindak dan berusaha untuk saling memenuhi kebutuhan satu dengan yang lain. Termasuk naluri untuk berinteraksi dengan sesamanya. Sebuah delik yang kemudian perlu menjadi perhatian bahwa kehidupan manusia selalu berada dalam dinamika diiringi dengan perubahan-perubahan yang selalu menuntut manusia untuk selalu beradaptasi. Era Revolusi Industri 1.0 hingga hari ini memasuki Era Revolusi Industri 4.0 seakan menjadi sebuah bukti nyata dinamika itu.

Menandai hal itu perkembangan teknologi yang terjadi kian pesat, juga telah merubah cara hidup kita termasuk dalam hal berinteraksi yang merupakan suatu kebutuhan manusia. Seperti yang dikemukakan Fonna (2019: 149) Sebelum era digitalisasi segala aspek kehidupan semua hanya berada dalam tradisi lisan hingga sekarang bergeser ke era tradisi digital, sejalan dengan itu memasuki era revolusi industri 4.0 aktivitas sosial atau komunikasi antar individu dan kelompok di dunia digital pun memunculkan cyber-social system.

Kemunculan cyber-social system seakan memperkuat adanya dominasi dunia maya yang kian melebur ke dalam kehidupan nyata manusia, juga sebagai pertanda bahwa dunia tidak sebatas jangkauan mata lagi. Mulai dari hadirnya jaringan internet yang terhubung ke komputer hingga kehadiran benda berukuran besar berantena, memakai keypad, hingga layar sentuh secanggih sekarang ini. Itulah bentuk revolusi smartphone sebagai bagian dari perangkat untuk menunjang tradisi digital.

Saat ini smartphone (Telepon Seluler) menjadi sesuatu yang sangat digandrungi terlebih lagi bagi generasi milenial. Berdasarkan beberapa pendapat para ahli dari berbagai negara dan profesi, penentuan siapa generasi milenial dapat ditarik kesimpulan bahwa generasi milenial adalah mereka yang dilahirkan antara tahun 1980 sampai dengan 2000. Selanjutnya konsep generasi milenial Indonesia adalah Penduduk Indonesia yang lahir antara tahun 1980-2000 (KPPPA, 2018: 16).

Dibandingkan generasi sebelumnya, generasi milenial memiliki karakter unik berdasarkan wilayah dan kondisi sosial-ekonomi. Salah satu ciri utama generasi milenial ditandai oleh peningkatan penggunaan dan keakraban dengan komunikasi, media, dan teknologi digital. Karena dibesarkan oleh kemajuan teknologi, generasi milenial memiliki ciri-ciri kreatif, informatif, mempunyai passion dan produktif. Dibandingkan generasi sebelumnya, mereka lebih berteman baik dengan teknologi. Generasi ini merupakan generasi yang melibatkan teknologi dalam segala aspek kehidupan. Bukti nyata yang dapat diamati adalah hampir seluruh individu dalam generasi tersebut memilih menggunakan ponsel pintar. Dengan menggunakan perangkat tersebut para millennials dapat menjadi individu yang lebih produktif dan efisien. Dari perangkat tersebut mereka mampu melakukan apapun dari sekadar berkirim pesan singkat, mengakses situs pendidikan, bertransaksi bisnis online, hingga memesan jasa transportasi online (KPPPA, 2018:18).

Di Indonesia, pemanfaatan telepon seluler (smartphone) dapat dilihat dari hasil Susenas 2017 menunjukkan bahwa memang generasi milenial lebih unggul jika dibandingkan dengan generasigenerasi sebelumnya. Pada Gambar 1 terlihat bahwa persentase generasi milenial di Indonesia yang menggunakan telepon seluler (HP)/ Nirkabel pada tahun 2017 sudah mencapai 91,62 persen. Persentase ini jauh lebih tinggi jika dibandingkan dengan Generasi $X$ yang sebesar 77,02 persen dan Generasi baby boom dan veteran yang hanya sebesar 43,72 persen (KPPPA, 2018:4).

Gambar 1. Persentase Penduduk di Indonesia yang Menggunakan Telepon Seluler (HP)/ Nirkabel Menurut Generasi dan Daerah Tempat Tinggal, 2017

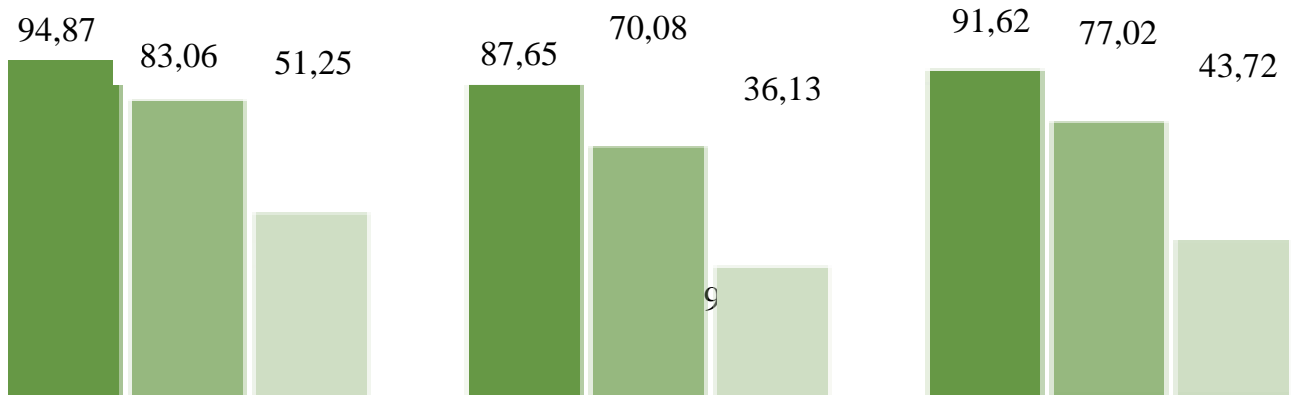


Perkotaan

Pedesaan

Total

Keterangan:

Generasi Y (Milenial)

Generasi X

Generasi Baby Boom+Veteran

Sumber: Survei Sosial Ekonomi Nasional (Susenas), BPS (KPPPA, 2018: 4).

Menurut Susenas 2017, jumlah generasi milenial mencapai sekitar 88 juta jiwa atau 33,75 persen dari total penduduk Indonesia. Proporsi tersebut lebih besar dari proporsi generasi sebelumnya seperti generasi $X$ yang $(25,74$ persen) maupun generasi baby boom+veteran $(11,27$ persen). Demikian juga dengan jumlah generasi $Z$ baru mencapai sekitar 29,23 persen (KPPPA, 2018: 22). Menurut Yoris Sebastian dalam bukunya Generasi Langgas Millennials Indonesia, ada beberapa keunggulan dari generasi milenial, yaitu ingin serba cepat, mudah berpindah pekerjaan dalam waktu singkat, kreatif, dinamis, melek teknologi, dekat dengan media sosial, dan sebagainya. (KPPPA, 2018: 19).

Beranjak dari popularitas smartphone yang tidak bisa dipisahkan dari kehidupan manusia dan menjadi kian digandrungi oleh genarasi milenial, sebenarnya tidak ada yang salah dari kehadiran smartphone tersebut karena setiap produk yang diciptakan itu mempunyai tujuan yang baik, hanya terkadang di dalam penggunaannya ada oknum yang menyalahgunakan ataupun sekedar berlebihan dalam penggunaannya. Disinilah kemudian titik tolak sebagai penggunaan smartphone yang tidak semestinya sehingga melahirkan gejala ataupun perilaku -perilaku sebagai akibat keberadaraannya.

Salah perilaku tersebut yaitu Phubbing. Phubbing merupakan kependekan dari Phone Snubbing. Phone Phubbing adalah kebosanan seseorang dalam berbincang secara langsung dengan lawan bicara atau dengan orang lain dan beralih berbincang dengan orang lain melalui smartphone (Juwita, 2019: 127). Phubbing adalah sebuah perilaku anti sosial yang lebih menyukai untuk berinteraksi melalui dunia maya dibanding dunia nyata. Fenomena Phubbing telah menyebar ke hampir setiap lapisan masyarakat baik tingkat Umur, Pekerjaan, Pendidikan maupun Jenis kelamin termasuk generasi milenial yang saat ini tidak luput dari cengkraman perilaku itu. Dulu sebelum smartphone ada melengkapi kebutuhan manusia dalam hal komunikasi acara keluarga atau berkumpul bersama teman dengan mengobrol dan bercanda satu sama lain. Tetapi sekarang kondisi itu sudah mulai terkikis hal ini berdasarkan yang penulis lihat di lapangan, di setiap tempat, dalam suasana bahkan dalam konteks acara apapun sering mendapati orang-orang yang duduk bersebelahan tetapi tidak berinteraksi mereka sibuk dengan smartphone masing-masing.

Mereka dekat tetapi seakan jauh karena tidak ada interaksi nyata yang terjalin padahal syarat untuk terjadinya interaksi adalah adanya komunikasi dan kontak sosial. Tetapi yang lebih menggelitik lagi orang-orang tersebut terlihat membuka beragam media sosial yang notabene merupakan tempat untuk berinteraksi di dunia maya. Seakan menjadi asumsi awal penulis bahwa orang yang melakukan phubbing menjauhkan orang yang dekat secara jarak dengannya tanpa interaksi atau sedikit berinteraksi, dan mendekatkan orang yang secara jarak jauh dengannya dengan interaksi di dunia maya.

Adapun penelitian terdahulu yang dilakukan oleh Ita Mustfirowati Hanika (2015) dengan judul Fenomena Phubbing Di Era Milenia (Ketergantungan Seseorang Pada Smartphone Terhadap Lingkungan menggunakan rancangan penelitian polling ini menggunakan 50 sampel yang dianggap bisa mewakili populasi. Hal ini dilatarbelakangi oleh ketergantungan seseorang terhadap smartphone dan menimbulkan kecemasan berlebihan jika tidak menggunakan perangkat tersebut. Temuan lain 
juga mengungkapkan bahwa sekalipun responden melakukan phubbing ternyata mereka juga merasa terganggu jika orang lain melakukan hal serupa.

Inta Elok Youarti, Nur Hidayah (2018) dengan judul Perilaku Phubbing Sebagai Karakter Remaja Generasi Z kemunculan istilah phubbing sebagai indikasi kecanduan generasi Z terhadap smartphone menjadikan seorang remaja rela menyakiti orang-orang yang ada di sekitarnya dengan bersikap acuh dan lebih terfokus pada smartphone yang ada di tangannya. Sementara itu, dari sisi bimbingan dan konseling, pendekatan CBT merupakan terapi yang sesuai dan dapat digunakan oleh seorang konselor untuk mengatasi perilaku phubbing tersebut. Dengan berkurangnya perilaku phubbing berkat upaya yang ada, diharapkan kepedulian sosial remaja bisa lebih ditingkatkan.

Varoth Chotpitayasunondh \& Karen M. Douglas (2018) dengan judul The effects of "phubbing" on social interaction. Hasil penelitian menunjukkan bahwa peningkatan phubbing secara signifikan dan negatif mempengaruhi persepsi kualitas komunikasi dan kepuasan hubungan. Efek-efek ini dimediasi oleh berkurangnya rasa memiliki dan pengaruh positif dan negatif. Penelitian ini menggarisbawahi pentingnya phubbing sebagai fenomena sosial modern untuk diselidiki lebih lanjut.

Muhammad Ali Ridho (2019) dengan judul Interaksi Sosial Pelaku Phubbing. Hasil penelitian ini menunjukkan interaksi sosial orang yang melakukan phubbing cenderung rawan terjadi saat mereka mengimitasi, mengidentifikasi peilaku dari orang-orang disekitarnya serta mengikis sifat simpati pada lawan bicara yang mengajak kita bicara selain itu juga timbul kontak sosial negatif yaitu kontak sosial atau komunikasi yang mengalami pertentangan, hilangnya sementara interaksi yang berlangsung bahkan kemarahan dari lawan bicara yang diabaikan.

Walaupun telah ada beberapa penelitian terdahulu mengenai Phubbing tetapi belum ada yang melakukan penelitian mengenai faktor penyebab dan pola interaksi yang yang dibangun generasi milenial di dunia maya saat melakukan phubbing. Atas dasar alasan tersebutlah selain memang fenomena phubbing ini memang menggelitik bagi penulis sehingga tertarik untuk melakukan penelitian dengan judul "Daya tarik Interaksi Dunia Maya (Studi Perilaku Phubbing pada Generasi Milenial di Kota Banjarmasin)".

\section{METODE PENELITIAN}

Penelitian ini menggunakan metode kualitatif. Seperti yang ditulis oleh Bogdan dan Taylor (Moleong, 2007) bahwa metode penelitian kualitatif merupakan suatu prosedur penelitian yang menghasilkan data deskriptif dengan pendekatan yang diarahkan kepada latar dan individu secara utuh sehingga mendapatkan data yang alamiah berdasarkan perspektif individunya. Seperti juga disebutkan oleh Faisal (1990) bahwa penelitian kualitatif berbentuk siklus dan bersifat terbuka terhadap kemungkinan melakukan perancangan ulang serta pengumpulan dan analisis data berlangsung simultan.

Teknik penentuan informan menggunakan tehnik purposive yaitu menentukan informan berdasarkan kualifikasi yang sesuai dengan topik penelitian. Dalam penelitian ini informan yang menjadi subyek penelitian adalah Generasi Milenial Pelaku Phubbing di kota Banjarmasin. Adapun kriteria dalam pemilihan informan adalah Seseorang yang lahir dari tahun 1980 hingga tahun 2000, Bertempat tinggal di Kota Banjarmasin, Berdasarkan keterangan Significant Order orang tersebut melakukan Phubbing saat berkumpul dengannya. Berkaitan dengan sumber data, data yang langsung diperoleh dari informan adalah termasuk data primer. Selain data primer dalam penelitian ini diperlukan juga data sekunder yang dikumpulkan melalui tehnik dokumentasi.

Teknik pengumpulan data dilakukan dengan pengamatan, wawancara, dan dokumentasi. Pengamatan dilakukan tehadap perilaku Phubbing yang di lakukan oleh generasi milenial ketika berkumpul dengan kelompoknya ataupun individu lain. Wawancara terhadap generasi milenial pelaku Phubbing dilakukan dengan tehnik wawancara semi terstruktur. Wawancara ini menggunakan panduan yang berisi garis besar pertanyaan penelitian, diharapkan pertanyaan akan berkembang sesuai dengan keadaan informan di lapangan. Melalui wawancara ini ditanyakan kepada informan berbagai pertanyaan sesuai fokus dan dapat dilacak pula hal-hal yang mungkin tersembunyi dalam 
diri informan (in-deept intervieu). Melalui tehnik dokumentasi dilakukan penelusuran dokumendokumen terkait dengan topik penelitian.

Klasifikasi analisa data menggunakan prosedur dari Miles dan Huberman (2000) yaitu tahap reduksi data, tahap penyajian data dan tahap penarikan kesimpulan. Pada tahap reduksi data dilakukan pemilahan data, mengkategorisasi data, dan merangkum data yang penting yang berkaitan dengan Generasi Milenial di kota Banjarmasin. Pada tahap penyajian data, peneliti mengorganisasikan dan menyusun data dalam suatu tulisan deskriptif sehingga dapat menguraikan temuan penelitian dengan jelas. Pada tahap penarikan kesimpulan, data yang sudah disajikan akan dianalisis sehingga terjadi elaborasi antara teori dan fakta yang terjadi di lapangan untuk mendapatkan kesimpulan akhir. Kesimpulan akhir dari keseluruhan aspek yang diteliti menjadi jawaban dari permasalahan penelitian.

Kredibilitas data dilakukan dengan tehnik triangulasi. Triangulasi yang akan dilakukan adalah triangulasi sumber dan triangulasi tehnik. Sumber data yang berbeda namun masih dalam ruang lingkup topik penelitian dapat menjadi cara triangulasi sumber. Dalam triangulasi tehnik dilakukan beberapa tehnik untuk konfirmasi data yaitu pengamatan, wawancara dan dukungan dokumen terkait.

\section{HASIL DAN PEMBAHASAN}

Sub bagian ini akan membahas tentang dua hal yang merupakan upaya menjawab rumusan masalah penelitian. Pertama, Faktor yang menyebabkan generasi milenial melakukan phubbing. Kedua, Pola interaksi yang dibangun generasi milenial di dunia maya saat melakukan phubbing. Dua hal tersebut akan dijelaskan satu persatu pada sub-sub bagian di bawah ini:

\section{Penyebab Generasi Milenial Melakukan Phubbing}

Kehadiran smartphone membawa dampak positif dan juga tidak terlepas dari dampak negatif. Salah satu dari dampak negatif itu adalah lahirnya perilaku Phubbing yang menjadi sebuah fenomena baru yang menghiasi kehidupan interaksi di masyarakat sekaligus sebagai ancaman bagi keberlangsungan interaksi langsung itu sendiri dengan hadirnya interaksi di dunia maya yang tidak lagi terbatas ruang dan waktu. Phubbing adalah sebuah perilaku antisosial yang tidak muncul begitu saja dan menjadi sebuah kebiasaan bahkan jika tidak ada yang menyebabkan itu terjadi. Bagian ini mencoba menganalisis apa yang menyebabkan generasi milenial melakukan phubbing, di tengah para phubber tersebut di kelilingi oleh teman bahkan orang-orang terdekatnya yang memungkinkan bagi mereka untuk saling berinteraksi secara nyata.

\section{a. Mengalihkan Perasaan Bosan}

Penuturan beberapa informan yang peneliti berhasil wawancarai yaitu $\mathrm{RN}$, dirinya mengaku bahwa ketika berbicara dengan teman kadang ada rasa bosan yang dirasakan sehingga dia lebih tertarik membuka smartphone untuk membaca komik ataupun membuka media sosial seperti instagram. Hal senada juga diungkapkan oleh informan OT yang juga merasa terkadang ada rasa bosan berada di sekitar temannya sehingga dia melakukan phubbing. Lebih lanjut OT menegaskan bahwa dirinya mengaku tidak marah jika orang lain melakukan phubbing terhadap dirinya sebab setiap orang punya kepribadian yang berbeda yang penting orang tersebut masih direspon saat dirinya sedang berbicara.

Dalam interaksi sosial dengan orang lain yang terwujud dalam komunikasi atau obrolan akan berisi umpan balik sebagai respon terhadap stimulus yang diberikan diantara orang yang berbicara maka sesuai dengan penuturan SN, saat orang lain berbicara dan dia merasa bosan maka SN lebih memilih bermain smartphone, walaupun tetap mendengarkan temannya berbicara dan memberikan umpan balik tetapi terkadang intensitasnya berkurang sebab fokusnya terbagi, yaitu mendengarkan teman berbicara dan juga sambil bermain smartphone atau melakukan phubbing. Kondisi yang berbeda menurutnya terjadi jika teman disekitanya tersebut asik dan nyambung diajak berbicara maka dia tidak akan melakukan phubbing. Walaupun dirinya sendiri mengakui bahwa interaksi dunia 
nyata tetap prioritas baginya tetapi saat bosan barulah dia beralih untuk melakukan phubbing dengan aktivitas biasanya melihat status teman atau berinteraksi dengan teman melalui dunia maya seperti Whatsapp atau Instagram tetapi dirinya juga menegaskan bahwa itu hanya sekedar selingan. SN menganggap bahwa perilaku phubbing memiliki manfaat bagi dirinya salah satunya untuk membantunya menghindari kondisi di sekitarnya yang terkadang tidak disukainya.

Hal yang sama juga diungkapkan NA bahwa faktor yang menyebabkan dirinya melakukan phubbing adalah rasa bosan dalam melakukan interaksi dengan orang sekitarnya apalagi jika pembahasan dengan temannya selalu sama. Walaupun dirinya mengaku bahwa tetap saja mendengar temannya bercerita sambil memainkan smartphone. RR juga sependapat bahwa perilaku phubbing dia lakukan untuk mengurangi rasa bosan saat mengobrol dengan temannya.

Berdasarkan penuturan beberapa informan diatas, dapat ditarik sebuah benang merah bahwa dalam sebuah interaksi sosial khususnya dalam berkomunikasi para generasi milenial sering melakukan phubbing untuk mengusir kebosanan dirinya. Hal ini berdasarkan apa yang dikemukakan oleh Juwita (2019: 127) bahwa Phubbing adalah kebosanan seseorang dalam berbincang secara langsung dengan lawan bicara atau dengan orang lain dan beralih berbincang dengan orang lain melalui smartphone. Perasaan bosan adalah perasaan yang berasal dari individu para pelaku phubbing. Bosan bisa terjadi jika tidak ada hal yang menarik dari obrolan, suasana atau bahkan halhal yang monoton lainnya. Terlebih lagi hal itu juga didukung fakta bahwa generasi milenial adalah generasi yang mudah bosan terhadap suatu hal. Ketika bosan itulah perilaku phubbing ini menjadi satu-satunya pilihan terbaik bagi para phubber, walaupun mereka sendiri mengetahui melakukan phubbing itu tidak baik.

\section{b. Menghindari Topik Pembicaraan Yang Tidak Disukai}

Berbicara mengenai interaksi sosial dengan orang disekitar kita, tidak menutup kemungkinan semua yang menjadi topik pembicaraan itu sesuatu yang kita sukai mengingat setiap orang punya persepsi yang berbeda terhadap suatu hal yang nantinya akan mengarahkannya pada sebuah perilaku. Begitupula yang dialami oleh informan SF dirinya mengaku bahwa ketika ada teman yang membahas topik pembicaraan yang tidak disukai seperti mengghibah orang lain, maka dia memilih untuk melakukan phubbing sebagai cara untuk menghindari obrolan pada saat tersebut.

Lebih lanjut Informan SF juga mengaku bahwa selain melakukan phubbing bersama teman, dirinya juga melakukan phubbing saat bersama keluarganya. SF melakukan phubbing karena dirinya menyadari sebagai anak milenial terkadang ada topik pembicaraan tertentu yang kurang disukai saat berkumpul bersama orang tuanya, sehigga dirinya lebih memilih melakukan phubbing walaupun terkadang ditegur oleh ibunya karena sangat jarang bagi mereka untuk kumpul bersama mengingat SF kuliah jauh dari orang tua. Termasuk phubber, bukan berarti bahwa SF menganggap perilaku phubbing itu baik, sebab berdasarkan penuturannya SF mengaku bahwa perilaku phubbing itu kurang baik, lebih lanjut menurutnya tipe manusia itu beragam yaitu ada manusia yang bisa fokus sama satu hal biasa sama dua hal. Jika manusia itu hanya bisa fokus pada satu hal maka konskuensi pembicaraan sambil melakukan phubbing adalah obrolan menjadi tidak nyambung dan dirinya juga merasa cukup kesal ketika menjadi korban phubbing temannya.

Sejauh ini dirinya juga mengakui bahwa pernah menegur temannya secara langsung saat lagi kumpul tetapi temannya malah sibuk main smartphone atau melakukan phubbing. SF tidak suka jika ada teman yang kumpul tetapi sibuk dengan hpnya sendiri. SF mengaku dalam dirinya pernah terbersit untuk menghilangkan perilaku phubbing sebab dirinya pernah merasakan tidak ada smartphone, dan keadaan itu yang jauh lebih baik dimana yang intensitas berkumpul makin lebih baik yang sangat berbeda dengan sekarang yang fokus pada smartphone masing-masing. Walaupun demikian dirinya masih menyadari betul bahwa saat ini kita sebagai manusia tidak bisa terlepas dari smartpohen sebab dibalik kekurangannya smartphone memiliki kelebihan yang teganya bahwa dirinya saja tidak bisa tanpa smartphone sehingga untuk mengatasi hal itu SF beranggapan hendaknya penggunaan smartphone disesuaikan dengan dengan kebutuhan sendiri. 
Senada dengan itu YD juga mengaku bahwa dalam melakukan obrolan dengan teman ada topik pembicaraan yang kurang menarik seperti berbicara mengenai harta sehingga untuk mengatasi hal itu YD mengaku melakukan Phubbing untuk menghindari pembicaraan teman akan hal tersebut walaupun masih tetap mendengarkan temannya berbicara agar dirinya sebagai sebuah pengalihan agar dirinya tidak keceplosan untuk mengungkapkan apa yang dirasakan. Sehingga secara garis besar dirinya juga mengaku bahwa lebih tertarik dengan dunia maya sebab banyak hal yang bisa dia lakukan termasuk membuka media sosial, bermain game apalagi game bola. YD juga menganggap bahwa tidak sopan jika melakukan phubbing disaat ada orang yang berbicara dengan kita. RR beranggapan bahwa ketika ada orang yang melakukan phubbing terhadapnya maka dirinya merasa kesal.

Hal yang sama juga diungkapkan oleh NA, yang juga melakukan phubbing jika temannya curhat dengan pembahasan yang sama berulang-ulang, maka dia tetap mendengarkan tetapi tetap melakukan phubbing saat temannya selesai berbicara dia pun menyimpan smartphone untuk kemudian memberikan tanggapan. Berdasarkan fakta yang diungkap para informan NA, YD, RR diatas tergambar bahwa salah satu penyebab individu melakukan phubbing sebagai pengalihan terhadap ketidaksukaan seseorang terhadap topik yang dibahas orang di sekitarnya.

\section{c. Teman Di Sekitar Juga Melakukan Phubbing}

Manusia adalah makhluk sosial yang dalam proses interaksinya menerima stimulus dari individu lain dan memberikan respon terhadap stimulus itu. Dikaitkan dengan perilaku phubbing yang saat ini banyak mendapat kecaman sebab dianggap sebuah perilaku yang menghina lawan bicaranya juga tidak luput dari hasil interaksi itu. Penuturan informan SN yang merupakan generasi milenial mengaku dirinya melakukan phubbing jika temannya yang sedang berada di sekitarnya juga melakukan hal yang sama. Asumsi pribadi SN daripada menunggu temannya tersebut selesai melakukan phubbing dirinya mengaku lebih memilih untuk juga melakukan phubbing. Terlihat jelas bahwa apa yang diutarakan SN itu merujuk kepada dirinya mengikuti apa yang dilakukan oleh orang disekitarnya yang walaupun dirinya sadar bahwa perilaku phubbing ini tidak baik untuk dilakukan apalagi jika sedang berkumpul bersama teman-teman, dan lebih lanjut dirinya juga sebenarnya kesal jika ada temannya yang melakukan perilaku phubbing ini jika berkumpul bersamanya, tetapi dirinya berusaha memaklumi hingga saling memahami bahwa itu sudah merupakan sebuah kebiasaan.

SN mengaku bahwa phubbing juga sebenarnya sebuah kewajaran pada saat tertentu sebab perkembangan teknologi semakin berkembang termasuk penggunaannya bagi manusia. Saat ada teman di sekitarnya melakukan maka dirinya juga akan melakukan phubbing, sebab sebuah kewajaran jika setiap pribadi mempunyai privasi masing-masing atau kesibukan kecuali saat dirinya berbicara dengannya dan yang dibuka itu penting jika tidak penting, dan yang dirinya bicarakan penting, tapi jika sebaliknya tidak masalah.

Berdasarkan dari penuturan para informan, terungkap pula bahwa semua informan menganggap bahwa phubbing adalah sebuah perilaku yang tidak baik dan dirinya sendiri tidak suka ataupun kesal jika menjadi korban phubbing oleh teman-temannya. Senada dengan itu, informan OT juga mengungkapkan jika ada teman disekitarnya yang melakukan phubbing maka dirinya juga akan mengikuti untuk melakukan phubbing sebab ada sebuah penafsiran dari dirinya bahwa orang yang mereka temani berinteraksi tidak menghargai kehadirannya, bahkan merasa dilecehkan dimana lawan bicaranya sibuk saja dengan smartphonenya sendiri sehingga dirinya juga melakukan hal yang sama. Hal ini sejalan dengan teori interaksi simbolik oleh Mead, bahwa dalam kehidupan sosial pada dasarnya, interaksi manusia menggunakan simbol-simbol yang semuanya punya makna yang diinterpretasikan individu yang sejalan dengan penafsiran mereka ketika berinteraksi. Selain itu fenomena perilaku phubbing sebagai respon yang diberikan oleh para phubber sesuai dengan stimulus yang didapatkan dari teman disekitarnya. Hal ini menunjukkan bahwa individu yang melakukan phubber ini sebenarnya juga adalah korban dari pelaku phubbing (phubber) yang terlebih dahulu melakukan phubbing pada orang di sekitarnya. 


\section{Pola Interaksi Yang Dibangun Generasi Milenial Di Dunia Maya Saat Melakukan Phubbing}

Interaksi sosial adalah suatu hubungan sosial yang menyangkut hubungan antar individu, individu dengan kelompok, dan kelompok dengan kelompok. Tanpa adanya interaksi sosial maka tidak akan mungkin ada kehidupan bersama. Sehingga keberadaan interaksi sosial yang terjalin antar individu menjadi sesuatu yang krusial untuk selalu dijalin bahkan dijaga keberlangsungannya di dalam masyarakat.

Secara teoritis, sekurang kurangnya ada dua syarat bagi terjadinya suatu interaksi sosial, yaitu terjadinya kontak sosial dan komunikasi (Narwoko, 2007: 10). Kedua syarat tersebut harus senantiasa terpenuhi ketika manusia melakukan proses interaksi baik dalam dunia nyata maupun dalam dunia maya. Menurut temuan survei menujukkan ada 4 tujuan yang paling sering dilakukan oleh milenial ketika terkoneksi dengan internet. Keempat tujuan tersebut antara lain chatting/messaging, browsing, jejaring sosial dan video streaming. Diluar empat tujuan itu ada musik, download, game online, email dan seabagainya (IDN Media, 2019: 59). Menurut Gillin, interaksi sosial adalah suatu hubungan sosial yang dinamis antara perorangan, antara individu, dan antar kelompok manusia. Dari pengertian tersebut, kita dapat membedakan pola-pola interaksi sosial dalam kehidupan sehari-hari (Paul, 1986: 32) yang kemudian kita selarasakan dengan fakta penelitian yang peneliti dapatkan di lapangan. Berikut ini pola interaksi yang dibangun generasi milenial ketika melakukan phubbing:

\section{a. Interaksi Sosial antar Individu.}

Intensitas koneksi yang cukup tinggi, millennial tidak bisa lepas dari smartphonenya. Apalagi, mayoritas millennial Indonesia mengakses internet melalui smartphone. Ada sebanyak 98,2 persen millennial menggunakan smartphone sebagai device utama ketika mengakses internet. Hal ini menunjukkan bahwa telepon seluler pintar (smartphone) merupakan gawai yang mereka bawa kemana-mana, dari mulai bangun tidur hingga tidur mereka membawa smartphone. Apalagi mayoritas mereka merupakan heavy user dan addicted user (IDN Media, 2019: 58).

Sebenarnya tidak ada yang salah ketika para milenial ini menggunakan smartphone hanya saja ada waktu tertentu juga yang seharusnya para generasi milenial ini mempertimbangkan untuk menggunakannya apalagi jika sudah menjurus kepada penggunaan yang berlebihan dan tidak memperdulikan orang yang ada disekitarnya atau melakukan phubbing. Apabila dua individu bertemu, proses interaksipun dimulai pada saat mereka saling menegur, berjabat tangan, dan berkomunikasi. Walaupun dua individu yang bertatap muka itu tidak saling mengadakan aktivitas, sebenarnya interaksi telah terjadi karena masing-masing pihak sadar akan adanya pihak lain yang menyebabkan perubahan perasaan dan syaraf orang-orang yang bersangkutan. Tetapi yang menjadi sebuah kejanggalan ketika para phubber ini juga berkumpul dengan individu lain di sekitarnya berinteraksi singkat sebelum akhirnya mereka sibuk dengan smartphone tanpa memperhatikan orang di sekitar. Padahal bertemunya seseorang dengan orang lain secara nyata atau badaniah tidak akan menghasilkan pergaulan hidup dalam suatu kelompok jika orang tersebut tidak bekerjasama, saling berbicara satu sama lain dan seterusnya untuk mencapai suatu tujuan bersama, mengadakan persaingan dan lain-lain seterusnya. Sebab interaksi sosial sendiri di bungkus oleh relasi sosial dengan karakteristik pelaku lebih dari satu orang, ada komunikasi antar orang yang berinteraksi, terjadi dalam dimensi waktu tertentu dan ada tujuan yang di capai.

Walaupun sekarang cakupan dari interaksi tidak terbatas atas ruang dan waktu, tetapi alangkah janggalnya jika ketertarikan untuk berinteraksi di dunia nyata lebih sedikit jika dibandingakan berinteraksi di dunia maya. Beginilah yang sedang dialami para phubber ini yang justru sibuk berinteraksi dengan orang di dunia maya. Mereka berinteraksi di dunia maya dengan pola interaksi antar individu baik itu di aplikasi media sosial berupa Whatsapp ataupun Instagram. Sesuai dengan penuturan SF yang mengaku bahwa dalam melakukan phubbing dirinya melakukan interaksi dengan individu lainnya di media sosial whatsapp karena dirinya menyenangi untuk fokus kepada satu hal untuk dibahas dengan seseorang dibandingkan dengan chat group.

Selanjutnya penuturan YD dirinya juga melakukan interaksi dengan individu lain saat melakukan phubbing terutama dengan orang terdekatnya yaitu pacarnya yang jaraknya jauh darinya. 
Berdasarkan penuturan informan diatas terungkap bahwa dalam melakukan interaksi di dunia maya pola interaksi yang terjadi antar individu dengan adanya perantara alat yaitu smartphone itu sendiri, padahal pada saat yang bersamaan phubber ini juga sedang berada di sekitar individu lainnya tetapi ada sebuah kecenderungan yang terjadi ketika interaksi di dunia maya lebih menarik perhatian mereka dikarenakan penyebab-penyebab yang ditelah diutarakan peneliti di sub bab awal bab ini.

Penuturan para informan memperlihatkan pola interaksi yang dijalin oleh para pelaku phubbing ini adalah pola interaksi individu di dunia maya, kenyataan ini mempertegas kembali adanya batasan yang akhirnya dilahirkan oleh smartphone dimana seharusnya ketika para individu berkumpul melakukan interaksi secara langsung dengan orang disekitarnya tanpa harus sibuk membangun pola interaksi lain di dunia maya.

\section{b. Interaksi Sosial Antar Individu dan Kelompok.}

Berinteraksi di dunia maya oleh para phubber ini menjadi sesuatu yang menarik. Banyak hal yang bisa mereka lakukan di dunia maya termasuk berinteraksi dengan banyak orang yang contohnya seperti chatting dengan komunitas. Berbicara Interaksi sosial, pola interaksi yang dijalin oleh para phubbing di dunia maya sampai tega mengenyampingkan interaksi dengan orang disekitarnya tidak hanya interaksi sosial antar individu dan individu tetapi individu dan kelompok juga seperti mengakses komunitas-komunitas yang ada di dunia maya seperti pengakuan RN.

Dilain sisi OT mengaku bahwa dirinya juga aktif untuk berinteraksi dengan kelompok atau group yang ada di whatsapp saat melakukan phubbing. Senada dengan OT, YD juga mengaku bahwa dirinya saat melakukan phubbing juga melakukan interaksi dunia maya berupa chat di room game PUBG, sehingga YD melakukan interaksi sosial saat phubbing dengan pola interaksi sosial individu dengan kelompok pemain game PUBG. Menambahi itu informan YD juga mengungkapkan secara gamblang kepada peneliti bahwa interaksi di dunia maya lebih menarik salah satunya menggunakan perantara smartphone sebab di smartphone memiliki banyak fitur-fitur salah satunya chat, ataupun games yang memungkinkan dirinya untuk melakukan interaksi dengan kelompok yang ada di dunia maya.

Senada dengan OT dan YD, RR juga sering melakukan interaksi kelompok di media sosial karena dirinya mengaku mempunyai beberapa group pertemanan di whatsapp seperti group keluarga ataupun group lainnya. Lebih lanjut juga RR menambahkan jika dirinya banyak bercanda di dalam grup yang ada di whatsapp baik itu group keluarga, kadang juga bertukar informasi, ataupun dengan group lainnya membicarakan soal agenda komunitas selanjutnya. Berdasarkan yang diutarakan oleh para informan penelitian ketika phubber ini berinteraksi di dunia maya terungkap bahwa pola interaksi individu dengan kelompok juga dilakukan oleh para phubber. Terjadinnya pola interaksi individu dengan kelompok memperlihatkan variasi interaksi baru dalam dunia maya dan sekaligus fakta bahwa antar individu dengan kelompok tidak selalu harus berkumpul secara nyata untuk bisa dikategorian berinteraksi tetapi berinteraksi di dunia maya menjadi sesuatu yang lumrah dan bahkan menarik untuk kebanyakan orang utamanya bagi informan dalam penelitian ini.

\section{KESIMPULAN}

1. Para generasi milenial tidak serta merta melakukan phubbing begitu saja sebab mereka juga menyadari bahwa perilaku phubbing tergolong perilaku yang tidak baik tetapi mereka tetap melakukannya. Penyebab para generasi milenial melakukannya yaitu mengalihkan perasaan bosan, menghindari topik pembicaraan yang tidak disukai, dan teman disekitar juga melakukan phubbing.

2. Berinteraksi di dunia maya oleh para phubber ini menjadi sesuatu yang menarik. Banyak hal yang bisa mereka lakukan di dunia maya termasuk berinteraksi dengan banyak orang yang contohnya seperti chatting. Ada pola interaksi yang dibangun generasi milenial di dunia maya saat melakukan phubbing adalah Interaksi Sosial antar Individu dan Interaksi Sosial Antar Individu dan Kelompok. 


\section{DAFTAR PUSTAKA}

Elok, Inta dan Nur Hidayah. (2018). Perilaku Phubbing Sebagai Karakter Remaja Generasi Z. Jurnal Fokus Konseling Universitas Negeri Malang. Diterbitkan.

Fonna, Nurdianita. (2018). Pengembangan industry 4.0 dalam berbagai bidang. Medan: Guepedia. Juntao, Michael. Nokia smartphone hacks. (2005). United States Of America: O' Reilly Media. Juwita, Lilis, et.al. (2019). Stop Phubbing. Jakarta: Rumah Media.

Kementerian Pemberdayaan Perempuan dan Perlindungan Anak dan BPS. (2018). Profil Generasi Milenial Indonesia. Jakarta: Kementerian Pemberdayaan Perempuan dan Perlindungan Anak. Mahmudah, Siti. (2010). Psikologi Sosial, Malang: UIN Maliki Press.

IDN Media. (2019). Indonesia Milenial report 2019. Jakarta: IDN Research Institute.

Narwoko. (2007). Sosiologi Teks Pengantar dan Terapan. Jakarta: Kencana

Paul, Doyle Johnson. (1986). Teori Sosiologi Klasik dan Modern. Jakarta: PT Gramedia, anggota IKAPI.

Ramadiani, (2018). Model dan bentuk penelitian E-Learning menggunakan structural Equation Model. Samarinda: Mulawarman University Press.

Yuwanto, Listyo. (2010). Mobile Phone Addict. Surabaya : Putra Media Nusantara.

Varoth, Chotpitayasunondh dan Karen M. (2018). The effects of "phubbing" on social interaction. Journal of Applied Social Psychology Douglas University of Kent, United Kingdom. Diterbitkan.

\section{Sumber Online :}

Kominfo.

(2019).

Mengenai

Generasi

Milenial

(online), https://www.kominfo.go.id/content/detail/8566/mengenal-generasimillennial/o/sorotan media. Diakses 27 November 2019. 